\title{
Decision Support System for Share Investment Using The Capital Assetpricing Method (CAPM)
}

\author{
$1^{\text {st }}$ Andriani Putri Wihartati, $2^{\text {nd }}$ Tino Feri Efendi \\ ${ }^{1,2}$ Institut Teknologi Bisnis AAS Indonesia Surakarta \\ ${ }^{1,2}$ Jl. Slamet Riyadi No. 361 Windan, Makamhaji, Kartasura, Sukoharjo, Indonesia \\ ${ }^{1}$ andrianipuwi@gmail.com, ${ }^{2}$ tinoferi8@gmail.com
}

\begin{abstract}
Investment is the placement of a number of funds at this time with the hope of obtaining benefits in the future. Stocks are one of the most popular investments. The current millennial generation is interested in investing in stocks because the capital required is not too large. However, in choosing a good stock for investment, the ability to read financial ratios is required. Errors in reading financial ratios will cause stock investment not to go as expected. To help with this, a system capable of supporting decisions is needed. There are several methods that can be used to produce a decision support system. In this study, the authors use the Capital Asset Pricing Model (CAPM) method in designing a decision support system in stock investment selection.The method in this research is through observation, interview, and literature study. The system design is made using Contex Diagram, HIPO, DAD, and database design. The system is made in a program with the PHP programming language. The process of determining the selection of stock investments using the Capital Asset Pricing Model (CAPM) method can simplify the determination process. Then with the method. can make it easier to determine the selection of stock investment.The final result in the stock investment selection process is a report that states investment $(R i>E)$ or not investment $(R i<E)$.
\end{abstract}

Keywords: Capital Asset Pricing Model (CAPM), Stock Investment, System

\section{INTRODUCTION}

Investment is a commitment to a number of funds or other resources carried out at this time, with the aim of obtaining a number of benefits in the future (Tandelilin, 2007). Investing in the capital market is always associated with risk. Investors must know the types of investment risks in order to calculate and even reduce the risks they must face. This type of risk is grouped into three major groups, namely systematic risk or called systematic risk, unsystematic risk, and total risk (Fahmi, 2012). Systematic risk is the risk that affects all types of stocks. If a systematic risk occurs, the investment made on one or more types of shares cannot cover the losses suffered. Examples of systematic risk are sharp increases in inflation and also increases in bank interest rates. Unsystematic risk is a risk that only affects a type of stock. If unsystematic risk occurs, investments made in other types of shares or sectors can cover the losses suffered.

Apart from dealing with risk, investing in the capital market is also related to the rate of return or return. Return is the profit obtained from the investment made. Risk and return in investment are two things that are interrelated and cannot be separated from one another. The expression that states that high risk will be followed by high return is indeed proven to be true because every return that will be obtained is directly proportional to the risk inherent in the stock.

The benefit of this research is that potential investors will understand better in determining investment options, or how to diversify their shares in order to get a bigger return. The purpose of this research is to make potential investors understand how to make stock selection and (diversification) by investing in many stocks so that the risk of loss in one stock can be covered by the benefits of other stocks and making the right decisions in choosing stocks.

When an investment is made for only one type of stock, when the stock experiences a profit, we will get a very large profit. As well as the reversal when the stock suffers a loss, we will also get a very large loss. Therefore, investors must have collections of stocks (portfolios) of different types or often referred to as stock diversification. Diversification aims to reduce existing investment risk by identifying the stocks to be selected and the proportion of funds to be invested in each share.

All rational investors will prefer efficient stocks, namely stocks that have lower expected returns than actual returns. "Efficient stocks can be determined by choosing a certain expected return rate, then minimizing the risk or minimizing a certain risk level, then maximizing the expected return" (Tandelilin, 2010). Inefficient stocks are stocks that must be avoided because these stocks have a small individual rate of return compared to the expected return. The Capital Asset Pricing Model (CAPM) method can be used to determine the magnitude of the relationship between risk and return obtained by investors so that it will help investors to avoid investment mistakes.

The definition of CAPM according to Bodie (2014) is a set of predictions regarding the balance of estimated returns on risky assets. CAPM is a model that connects the expected return rate of a risky asset with the risk of an asset in a balanced market condition (Tandelilin, 2010). CAPM calculation, namely the return expected by investors for invested shares will be influenced by the systematic risk inherent in these shares. The greater the systematic risk of a stock, the greater the chance of return that will be obtained. The main objective of implementing CAPM is to determine the level of expected return in minimizing risky investment. CAPM can also help investors in calculating the risk that cannot diversify in a portfolio and compare it with the predicted rate of return (return).

The results of Yesicca's research (2009) using the CAPM method and the sample tested were stocks listed in JII, resulting in 5 stocks out of 9 samples that were worthy of investment. The criteria used in this study are to see the correlation and linearity of risk and stock returns as well as significant beta values. Meanwhile, research conducted by Nasuha, et al (2013) with a sample of stocks from companies in the property and real estate sector, using the CAPM analysis method obtained results. 
International Journal of Computer and Information System (IJCIS)

Peer Reviewed - International Journal

Vol : Vol. 02, Issue 01, February 2021

e-ISSN : 2745-9659

https://ijcis.net/index.php/ijcis/index

\section{RESEARCH METHODS}

This research is classified as a quantitative descriptive study. Descriptive research is making a systematic, factual, and accurate depiction of the facts and characteristics of a particular population or area (Suryabrata, 1983). According to Boyd, Westfall, and Stasch (1989) in Kuncoro (2007) descriptive research or studies seek to obtain a complete and accurate description of the situation.

Research with quantitative methods is a scientific approach to managerial and economic decision making. This approach starts with data. Processing and manipulation of raw data into useful information is the essence of quantitative analysis.

\subsection{Data Collection Methods}

The following data collection methods are as follows: Interview : Interviews were conducted to obtain complete information from sources, namely administration. The interview aims to ask for information from the administration section about the procedure for receiving merit and underprivileged scholarships. As for some of the questions that the author asks the administration section are as follows : What are the requirements for investing?, What is the process for investing?, How to determine investment options? Observation : Namely making direct observations on how the stock investment process is. Literature study : Namely, by finding the necessary references or theories through scientific books or journals that are related to the problems of making a decision support system for stock investment choices.

Data retrieval from the Indonesia Stock Exchange was obtained through www.idx.co.id and www.yahoofinance.com. Data collection was conducted in January 2021, and interest rates were obtained from the Bank Indonesia website www.bi.go.id.

Types of Data The type of data used is secondary data, namely from the closing stock price (closing price) per month during the 2019 period, the BI rate, and the Kompas Market Index 100. Data collection in research was carried out by means of library research and research through the media. Internet.

\subsection{Systems Development Method}

The following methods in system development are as follows : System Planning : The data analysis technique uses the Capital Asset Pricing Model method. This research was conducted with the aim of finding an overview of the stock investment decision making by investors using the Capital Asset Pricing Model method on the Kompas 100 Index.

The calculation is done using the Microsoft Excel program. Analysis of the application of the CAPM method in determining investment is done by : 1 . Collecting data on shares included in the Kompas 100 Index for the 2019 period, namely data on closing prices at the end of the month. 2. Calculate the profit rate of each share. 3. Return is the result obtained from investment. Return realization is the return that has occurred, calculated based on historical data. It can be calculated by the formula for calculating the profit rate of each share (Jogiyanto, 2010). 4. Calculating the profit rate of the market profit rate. 5. Calculating the profit rate of the composite stock index can be seen as follows (Jogiyanto, 2010). 6. Calculate stock Beta, 7. Security Market Line description, 8. Classification of Shares as an Investment Decision. System Analysis : In this system analysis stage the author will discuss the steps for making a decision support system, namely: 1. Intelligent Stage, This stage is the process of tracing and identifying problems. The data obtained is data that can be used to assist the decision-making process. These data are the closing stock price (closing price) per month during the 2019 period, the BI rate, and the Kompas Market Index 100 2. Design Stage : This stage is the stage where the process of selecting companies for stock investments. 3. Selection Stage (Choice) : This stage is the analysis stage of selecting companies for stock investment using the Capital Asset Pricing Model calculation based on the available criteria. 4 . Implementation Stage (Implementation) : This stage is the implementation stage of the three phases that have been designed into a decision support system application using the Capital Asset Pricing Model method so that users can more easily determine stock investment. System Design : In this stage the writer will make a system design consisting of: Context Diagram, Context diagrams are used to show or describe data flows throughout the network, input and output. Identify the beginning and end of data, the beginning and end of the entry and output of the system. HIPO, HIPO tiered charts are used for levels providing a clear explanation of the inputs that must be used and the outputs that must be generated by each function at each level of the HIPO diagrams. A tiered chart for this system contains processes that can be described accordingly. According to Raymond Mcleod. JR. (2008) "A management information system is a computer-based system that makes information available to users with similar needs." Managers at the top of the organizational hierarchy, such as directors and deputy directors, are often said to be at the strategic planning level. Middle-level managers include area managers, directors, products, and heads of divisions. The early level of management is called the level of management control. Lower-level managers include department heads, supervisors, and project leaders, who are responsible for completing plans set by higher-level managers. This lowest level is called the level of operational control.

Investments are basically made with the intention of expecting a certain amount of profit in the future by investing in the present. Investment is a delay in current consumption for use in efficient production for a certain period of time (Jogiyanto, 2012: 5).

The objectives of investing in stocks which are classified as long-term investments are to supervise other companies, get fixed income each period, form a special fund, ensure continuity of supply of raw materials, and to maintain relationships between companies (Baridwan, 2004: 227)

DSS as a computer-based system that assists in the decision-making process. DSS as an adaptive, interactive, flexible computer-based information system, which is specifically developed to support solutions to unstructured management problems to improve the quality of decision making. With this it can be defined about the DSS, which is 
International Journal of Computer and Information System (IJCIS)

Peer Reviewed - International Journal

Vol : Vol. 02, Issue 01, February 2021

e-ISSN : 2745-9659

https://ijcis.net/index.php/ijcis/index

a computer-based system that is adaptive, flexible, and interactive which is used to solve unstructured problems so as to increase the value of decisions taken (Khoirudin, 2008)

Capital Asset Pricing Model (CAPM) describes the relationship between return and beta. Understanding CAPM was first introduced in the mid-1960s by Willian F. Sharpe, Linter and Mossin. William F. Shape is a Professor of Finance at Stanford University Graduate School of Business. To calculate the level of portfolio profit, investors need an analysis. The establishment of general equilibrium models allows investors to define relevant risk measures. One of the existing balance models is CAPM.

CAPM is an equilibrium asset pricing model which states that the expected return on a particular security is a positive linear function and the security's sensitivity to changes in its market portfolio returns. The following is the definition of CAPM according to Elton \& Gruber:

"A model based on the proposition that any stocks's required rate of return is equal to the risk free of return plus a risk premium, where risk reflect diversification"

According to Gitman and Zutter (2012: 329), there are two types of risk in CAPM. The first is unsystematic risk and the second is systematic risk. When the two types of risk are combined, it is called total risk. Although the Capital Asset Pricing Model cannot be proven empirically, the CAPM Model is widely used because this model has a fairly good accuracy in determining the return of a stock. The CAPM model assumes that investors are planners in a single period who have the same perception of market conditions and look for the mean-variance of the optimal portfolio (Andri, 2010). Based on some of the opinions of the experts above, basically, the Capital Asset Pricing Model (CAPM) is a model or way to estimate the return value of an asset by comparing the return variable received and the risk borne. The purpose of using this model is to determine the level of expected return (expected return) of risky assets and to calculate the risk that cannot be diversified (unsystematic risk) in a portfolio and compare it with the predicted rate of return (return).

The creation of PHP was started in 1994 by Rasmus Lerdorf who was originally used for counting and to find out who had visited his homepage. PHP is an open source software that is regulated in the GPL (General Purpose Licenses) rules which are very suitable to be developed in a web environment, because PHP can be placed in HTML or PHP scripts.

PHP is classified as a server-side scripting language, which means that all PHP scripts are placed on the server and translated by the web server first, then the translation results are sent to the client browser. This is different from Java Script. The Java Script program code must be downloaded first on the client computer, then translated by an internet browser. technologically the PHP programming language has similarities with the ASP (Active Server Page), Cold Fusion, JSP (Java Server Page) or Perl (Suprianto, 2008). The creation of PHP was started in 1994 by Rasmus Lerdorf which was originally used to record the number and to find out who has visited its homepage. PHP is an open source software that is regulated in the GPL (General Purpose Licenses) rules which are very suitable to be developed in a web environment, because PHP can be placed in HTML or PHP scripts.

PHP is classified as a server-side scripting language, which means that all PHP scripts are placed on the server and translated by the web server first, then the translation results are sent to the client browser. This is different from Java Script. The Java Script program code must be downloaded first on the client computer, then translated by an internet browser. Technologically, the PHP programming language has similarities with the ASP (Active Server Page) language, Cold Fusion, JSP (Java Server Page) or Perl (Suprianto, 2008).

MySQL is one type of database server that is very well known and widely used. This is because MySQL uses SQL (Structure Query Language) as the basis for accessing the database. MySQL includes RDBMS (Relational Database System) which is more popular through web programming, especially in Linux environment. However, currently available for the Windows 98 / ME / 2000 / XP OS platform (Saputro, 2005).

MySQL is a software SQL database management system (English: database management system) or DBMS that is multithreaded, multi-user, with about 6 million installations worldwide. MySQL is a Relational Database Management System (RDBMS) which is distributed free of charge under the GPL (General Public License). where everyone is free to use MySQL, but cannot be made a commercial derivative product. MySQL is actually a derivative of one of the main concepts in databases for a long time, namely SQL (Structured Query Language). (Fauzial Batawi, 2011).

\section{III.RESULT AND ANALYSIS}

In the discussion, discussing the results of research in the form of system design as a whole are as follows:

\subsection{Computerized System Analysis}

System analysis is the earliest stage of system development which is the foundation for determining the success of the resulting information system. Systems analyst is a term that collectively describes the early phases of early development. According to Al Fatta (2001: 6) system analysis is the decomposition of a complete information system into its component parts in order to identify and evaluate the expected problems so that improvements can be proposed. System analysis systematically assesses how it functions by observing the input process and the data output process information to help improve organizational processes. Thus, system analysis has three important roles, namely: 1) As a consultant, 2) As a supporting expert, 3) As a change expert.

In line with the above understanding, Taufiq (2013: 153), system analysis is an activity to study the system (either manual or computerized systems) as a whole starting from analyzing the system, analyzing problems, designing logic, and making decisions from the results of the analysis. 
International Journal of Computer and Information System (IJCIS)

Peer Reviewed - International Journal

Vol : Vol. 02, Issue 01, February 2021

e-ISSN : 2745-9659

https://ijcis.net/index.php/ijcis/index

\subsection{System Design}

This section contains an explanation of system design for

The design stage has the goal of designing a new system that can solve the problems faced by the company obtained from choosing the best alternative system. Regarding this, Al Fatta (2007: 24) explains that the analysis and design of information systems is a complex organization in which computer-based information systems are implemented. Meanwhile, according to Jogiyanto (in Taufiq, 2013: 168)

\section{Contex Diagram}

Context Diagram is the highest level in the data flow diagram and contains only one process, showing the system as a whole. The process is numbered zero. All external entities are shown on the following context diagrams - the main data flows to and from the system. The diagram does not contain data stores and appears simple to create, once external entities and data flows to and from the system are known to the analyzer.

interviews with users and as a result of document analysis. Context diagrams underline a number of important characteristics of a system: 1) User groups, organizations, or other systems where our system communicates which is also known as a terminator. 2) Data which our system receives from the environment and must be processed in a certain way. 3) Data that our system generates and gives to the outside world. 4) Data storage that is shared between our system and the terminator. This data is created by the system and used by the environment or vice versa , created by the environment and used by our system. 5) The boundaries between our system and the environment.

Context Diagram begins with the depiction of a terminator, data flow, storage control flow, and a single process that shows the entire system. The easiest part is to define a process (which consists of only one circle) and give it a name that represents the system. The name in this case can describe the process or job or in extreme cases the name of the company which in this case represents the processes carried out by the whole organization.

Terminator is shown in rectangular shape and communicating directly with system via data stream or external storage. Inter-terminator is not allowed direct communication. In fact, the relationship between the terminators is done, but definitively because the terminator is part of the environment, it is not relevant if it is discussed in the context diagram.

\section{HIPO}

HIPO (Hierarchy Input Process Output) is a methodology developed and supported by IBM. HIPO is actually a program documentation tool. However, nowadays, it is widely used as a design tool and documentation technique in the function-based system development cycle, where each module in the system is described by its main function.

According to Jogiyanto HM in the book Information Systems Analysis \& Design (2005: 787) HIPO (Hierarchy plus Input-Process-Output) is a design tool and documentation technique in the system development cycle. HIPO (Hierarchy plus Input-Process-Output) has the following main objectives: 1) To provide a structure to understand the functions of the program. 2) To put more emphasis on the functions that must be completed by the program, instead of showing the program statements that are used to carry out the function. 3) To provide a clear explanation of the inputs to be used and the outputs that each function should produce at each level of the HIPO diagrams. 4) To provide the right output and in accordance with the needs of the user.

\section{DAD (Data Flow Diagram)}

Data Flow Diagrams (DAD) (Data Flow Diagrams) or DFD are "A graphical representation of a system that uses a number of symbols to describe how data flows through an interrelated process". Although the name of this diagram emphasizes data, the situation is the opposite the emphasis is on process. DAD describes the flow of system data, the use of which is very helpful for understanding the system in a logical, structured and clear manner.DAD functions: 1) DAD helps system analysts summarize information about the system, know the relationship between sub-systems, help develop applications effectively. 2) DAD functions as a good communication tool between users and system analysts. 3) DAD can describe a number of automation limitations for the development of alternative physical systems. development of alternative physical systems.

\subsection{SWOT Analysis}

SWOT analysis is a simple but very powerful tool for measuring the capacity of an organization's resources and shortages, market opportunities, and external threats in the future (Thimpson et al., 2007, p. 97). As a tool used for strategic planning and management in a company, SWOT is useful for building effective organizational and competition strategies. SWOT is very important in the process of analyzing the company's interactions with the internal and external environment.

Strength (Strength) : Can be used for short-term calculations; The required data is easy to get; It doesn't take long to estimate returns

Weakness : Only consider market risk as the sole risk in estimating stock returns. Thus, the estimation results are less accurate.

Opportunities (Opportunities) : There are not many stock investment system applications. Stock investment will be in great demand.

Threats : The development of technology will emerge various developments in this investment system.

\section{CONCLUSION}

At the end of this pentup is made in the form of conclusions and suggestions, namely as follows: Based on the results of the research and discussion that has been carried out, it can be concluded that the results of the decision support system in stock selection using the CAPM method can be used as a recommendation for investors in choosing optimal stock investment. The implementation of a decision support system in stock selection can make changes to the criteria and alternatives data, so that the evaluation of the development of alternative stocks can be determined as needed. The results of the research above, there are several things that need to be added and developed 
International Journal of Computer and Information System (IJCIS)

Peer Reviewed - International Journal

Vol : Vol. 02, Issue 01, February 2021

e-ISSN : 2745-9659

https://ijcis.net/index.php/ijcis/index

for further research including, the next researcher can use other methods in finding weights, for example the CAPM method. Stock selection analysis can apply a combination of other methods so that it can be used as a comparison of the weight or ranking produced. Decision Support Systems can be developed into group decision support.

\section{REFERENCES}

[1] Lemiyana. 2015. Analysis of CAPM and APT Models in Predicting Sharia Stock Return Rate (Case Study of Shares in the Jakarta Islamic Index). Palembang: Raden Fatah State Islamic University.

[2] Muqorobin, M., Rais, N. A. R., \& Effendi, T. F. (2020). SISTEM INFORMASI KELURAHAN KRIKILAN BERBASIS WEB. BUDIMAS: JURNAL PENGABDIAN MASYARAKAT, 2(2).

[3] Martono., \& D. Agus Harjito. 2010. Financial Management. Yogyakarta: ECONISIA.

[4] Seftyanda, Bunga Engineering et al. 2014. Analysis of the CAPM Method as a Basis for Making Stock Investment Decisions on All Shares Listed on the IDX for the 2010-2012 Period. Malang: Brawijaya University..

[5] Gunawan, Wahyu. 2010. Kebut a day to be a PHP master. Yogyakarta. Publisher Genius Publisher.

[4] Hermawan, Julius. 2005. Building a Decision Support System. Yogyakarta: Andi.

[5] Grace. 2007. Introduction of SQL. From http://rahmat.polinpdg.ac.id/content/view/62/64/. $10 \quad$ June 2010.

[6] Muqorobin, M., \& Rais, N. A. R. (2020). Analysis of the Role of Information Systems Technology in Lecture Learning during the Corona Virus Pandemic. International Journal of Computer and Information System (IJCIS), 1(2).

[7] Muqorobin, M., Kusrini, K., Rokhmah, S., \& Muslihah, I. (2020). Estimation System For Late Payment Of School Tuition Fees. International Journal of Computer and Information System (IJCIS), 1(1).

[8] Solihin, Ahmad, MySQL 5 From Beginner to Advanced, Achmatim. net. Jakarta. https://www.firebase.com/features.html, accessed September 26, 2015.

[9] Muqorobin, M., Rokhmah, S., Muslihah, I., \& Rais, N. A. R. (2020). Classification of Community Complaints Against Public Services on Twitter. International Journal of Computer and Information System (IJCIS), 1(1).

[10] Muqorobin, M., \& Rais, N. A. R. (2020, November). ANALISIS PERAN TEKNOLOGI SISTEM INFORMASI DALAM PEMBELAJARAN KULIAH DIMASA PANDEMI VIRUS CORONA. In Prosiding Seminar Nasional \& Call for Paper STIE AAS (pp. 157-168).
[11] Utomo, I. C., Rokhmah, S., \& Muslihah, I. (2020). Web Based Distribution of Zakat, Infaq, and shodaqoh (Case Study Of Surakarta City Region). International Journal of Computer and Information System (IJCIS), 1(1).

[12] K. Kusrini, E. T. Luthfi, M. Muqorobin and R. W. Abdullah, "Comparison of Naive Bayes and K-NN Method on Tuition Fee Payment Overdue Prediction," 2019 4th International Conference on Information Technology, Information Systems and Electrical Engineering (ICITISEE), Yogyakarta, Indonesia, 2019, pp. 125-130, doi: 10.1109/ICITISEE48480.2019.9003782.

[13] Muqorobin, M., Hisyam, Z., Mashuri, M., Hanafi, H., \& Setiyantara, Y. (2019). Implementasi Network Intrusion Detection System (NIDS) Dalam Sistem Keamanan Open Cloud Computing. Majalah Ilmiah Bahari Jogja, 17(2), 1-9.

[14] Muqorobin, M., Apriliyani, A., \& Kusrini, K. (2019). Sistem Pendukung Keputusan Penerimaan Beasiswa dengan Metode SAW. Respati, 14(1).

[15] Abdullah, Robi W., et al. "Keamanan Basis Data pada Perancangan Sistem Kepakaran Prestasi Sman Dikota Surakarta." Creative Communication and Innovative Technology Journal, vol. 12, no. 1, 2019, pp. 13-21.

[16] Saputra, R., \& Rais, N. A. R. (2020). Online Sales System Analysis of PT. Nutrifood Indonesia through the distributor CV. Trio Sukses Mandiri Solo With Nutrimart Home Delivery (NHD) Application. International Journal of Computer and Information System (IJCIS), 1(2).

[17] Muslihah, I., Muqorobin, M., Rokhmah, S., \& Rais, N. A. R. (2020). Texture Characteristic of Local Binary Pattern on Face Recognition with PROBABILISTIC LINEAR DISCRIMINANT ANALYSIS. International Journal of Computer and Information System (IJCIS), 1(1).

[18] Hikmah, I. N., \& Muqorobin, M. (2020). Employee Payroll Information System On Company Web-Based Consultant Engineering Services. International Journal of Computer and Information System (IJCIS), 1(2).

[19] Nastura, S. A., \& Muqorobin, M. (2020). Transaction Processing System Analysis Using The Distribution Management System (DMS) Nexsoft Distribution 6 (ND6). International Journal of Computer and Information System (IJCIS), 1(2).

[20] Muqorobin, M., \& Rais, N. A. R. (2020). Analysis of the Role of Information Systems Technology in Lecture Learning during the Corona Virus Pandemic. International Journal of Computer and Information System (IJCIS), 1(2). 